\title{
Industrialization and Youth Unemployment in Nigeria: An Autoregressive Distributive Lag (ARDL) Approach
}

\author{
Johnson Akpan Atan, Ubong Edem Effiong* \\ Department of Economics, Faculty of Social Sciences, University of Uyo, Uyo, Nigeria \\ Email address: \\ ubongeffiong3@gmail.com(U.E.Effiong) \\ ${ }^{*}$ Corresponding author
}

\section{To cite this article:}

Johnson Akpan Atan, Ubong Edem Effiong. Industrialization and Youth Unemployment in Nigeria: An Autoregressive Distributive Lag (ARDL) Approach. International Journal of Business and Economics Research. Vol. 9, No. 5, 2020, pp. 324-334.

doi: $10.11648 /$ j.ijber.20200905.15

Received: August 11, 2020; Accepted: August 20, 2020; Published: September 21, 2020

\begin{abstract}
This paper is an empirical investigation into the role of the industrial sector in curbing youth unemployment in Nigeria using time series data that covers the period 1991 to 2019. The data were subjected to unit root test using the Augmented Dickey Fuller and Philip-Peron test techniques. THE data was analysed using the ARDL approach and Granger causality test. The result of the unit root test reported that the variables were integrated in mixed order of levels and first difference. This mixed order of integration necessitated the use of the ARDL Bounds test for cointegration. From the bounds test, there exist a long-run/levels relationship between youth unemployment and the explanatory variables. Also, the error correction term $(-0.6215)$ showed that $62.15 \%$ of the short-run disequilibrium is corrected annually. The result further revealed that industrial output exerts a negative effect on youth unemployment both in the short-run and in the long-run. This implies that increasing the volume of industrial activities will reduce youth unemployment. The Granger causality test also showed that there exists causal relationship between youth unemployment and industrialization in Nigeria. The paper therefore recommended the need for boosting industrialization in Nigeria as it will curb massive youth unemployment in the country rather than advocating on entrepreneurship. This is because a strong industrial base will spring up more jobs than new ventures who are noted for folding up within few years of operations.
\end{abstract}

Keywords: Youth Unemployment, Industrialization, Bank Credit, ARDL, Cointegration

\section{Introduction}

Youth unemployment has been regarded as one of the serious threats endangering the progress of Nigeria. The term refers to the conglomerate of youths with diverse background, willing and able to work but cannot find employment [1]. This, based on the classical theory of unemployment, is as a result of excess of labour supply over demand. The population of youths have been maintaining an upward movement over the years and this can be seen as one of the challenging issues though the economy has been characterized with gross absence of employment opportunities over the years. For instance, the population of youths (15-34 years of age) was $27,335,153$ as at 2010 but increased to $33,927,916$ as at 2013 , with a further increase to as high as 44,229,419 as at third quarter of 2018 [2]. This has made diverse groups to strive for entrepreneurship and temporary youth-based rather than laying a solid foundation for this important segment of the population to thrive.

The consequences of youth unemployment are enormous, cutting across social, political, and economic dimensions. The political dimension captures the little or no concern for government issues, activities and policies, and programs. The youths feel marginalized and neglected in their quest for survival. Strands of civil unrest in the country ranging from Boko Haram in north-east and bandits in the north-west to militancy in the south-south are all issues of national concerns that are executed by the youths. In Egypt, the youths were key players in the overthrow of President Hosni Mubarak on 11th February 2001 leading to a state of anarchy in the country. The high rate of political thuggery, civil unrest, and kidnapping in Nigeria can be traced to youth unemployment in the country. This has raised serious 
concerns for leaders like General Ibrahim Babangida (Rtd) and Chief Olusegun Obasanjo. They blamed these crises on youth unemployment stating that "idle hands are always devil's instrument and that if people were fully engaged, they would hardly have the time to see others as their enemies". He further stated at the 100th International Labour Conference in Geneva that "Nigeria was sitting on a keg of gun powder given the rate of unemployment which can lead to revolution, and that hopeless idle hands are not only a devil's workshop, but also a tinder box" [3].

On the economic perspective, unemployment leads to loss of potential output and the economy will be operating below full capacity. The economy will be producing inside her production possibility frontier indicating inefficiency. The loss of output results in shortages thereby mounting inflationary pressure in the economy [4]. In a period of high unemployment, youths can lose their skills causing a loss of human capital. Also, it could lead to low level of income and high rate of income inequality which further aggravates the high rate of poverty. The social dimension manifests in areas such as susceptibility to malnutrition; illness and mental stress; subsequent loss of self-esteem leading to depression; excessive alcoholism and drug abuse; dysfunctional social and emotional relationships; loss of self-confidence; feeling of shame and failure; lost opportunities to good education and healthcare for the children and the family; limiting family access to good housing; increased vulnerability of family members especially women, children and elderly; and creation of tension and conflict such as domestic violence.

The employment status of the youthful population has been characterised by both unemployment and underemployment. As at 2010, youth unemployment rate stood at $6.8 \%$ with an underemployment rate of 21.9 while in 2013 , unemployment rose to $12.5 \%$ while underemployment declined to $19.2 \%$ [2]. Similarly, unemployment rose from $10.43 \%$ in first quarter of 2015 to $19.39 \%$ in the last quarter of 2016 , representing an $85.91 \%$ increase over the period. However, underemployment rose from $22.9 \%$ to $28.0 \%$ averaging $25.55 \%$ within the same period. As at third quarter of 2018, youth unemployment stood at $29.72 \%$ with attendant underemployment rate of $25.7 \%$. This is replicated in Figure 1.

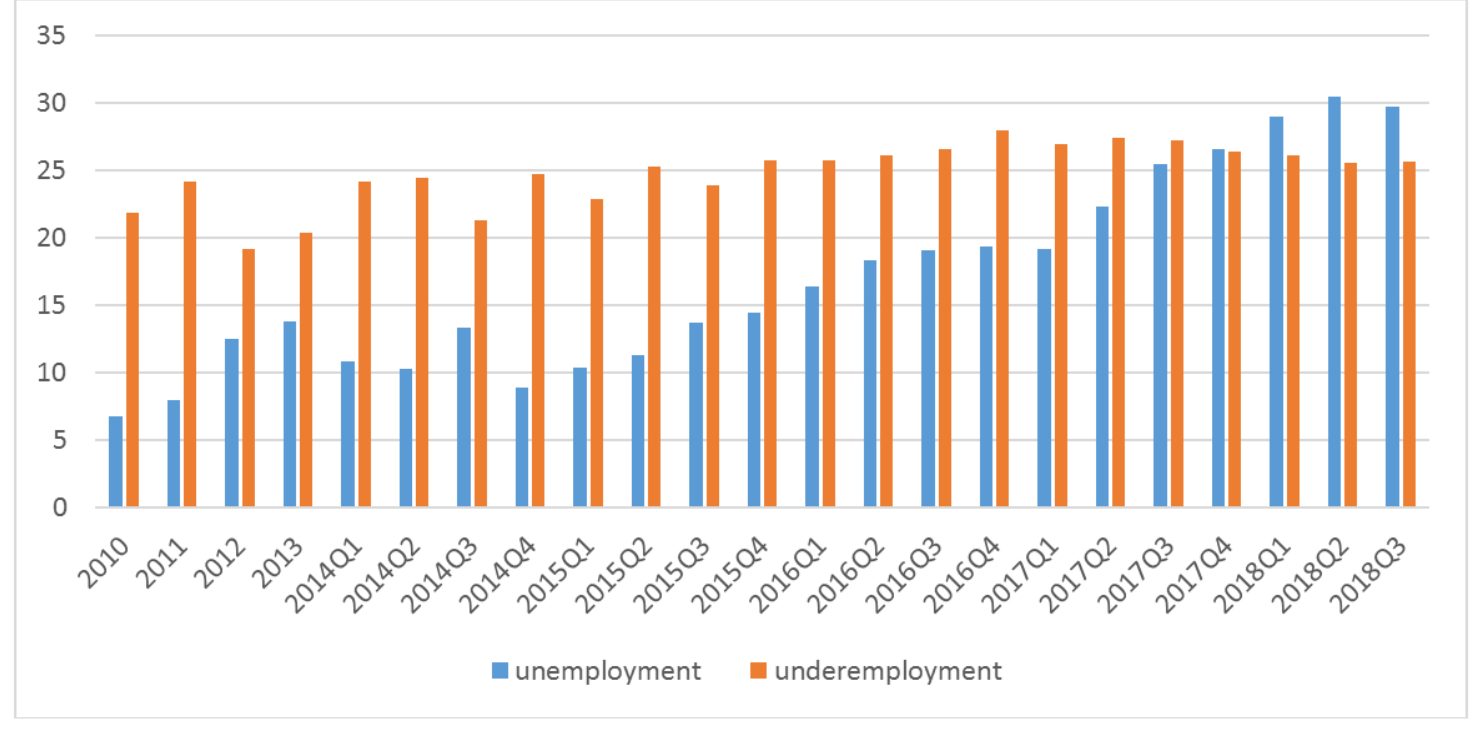

Figure 1. Youth unemployment and underemployment 2010-2018Q3.

Evidence from Figure 1 indicates that underemployment is also a serious problem in the youth population of Nigeria. It is observed that prior to 2010 to the third quarter of 2017 , youth unemployment has been greater than youth underemployment. However, the situation was the opposite from the fourth quarter of 2017 to the third quarter of 2018.

This alarming rate of unemployment and underemployment and its attendant implication for development calls for alarm at all levels of government. This has led to various schemes such as the National Directorate of Employment (NDE) and National Economic Empowerment and Development Strategy (NEEDS). Meanwhile, a strongly industrialized economy is believed to create more employment opportunities for the population hence, industrialization is regarded as a catalyst for job creation [5]. This is because industrialization can promote access to capital, technological innovation, and learning [6]. Thus, industrialization is seen as major policy that can stimulate economic development and social progress [7] hence, the need for structural transformation of the agricultural sector into value added activities which of course is tending towards industrialization. The promotion of industrialization is of top priority and the purpose is often to create labour-intensive industries.

The Nigeria industrial sector have been recording s steady rise in output over the years and youth unemployment has been on the rise. For instance, the value of industrial output as at 1991 stood at $\$ 8,574.51$ billion and increased to $\$ 10,192.30$ billion as at 2001 . The figure rose steadily to $\$ 13,826.43$ billion in 2010 with a further increase to $\$ 16,742.15$ billion as at 2014 . The value declined to $\$ 15,882.35$ billion as at 2019 [8]. This is illustrated in Figure 2. 


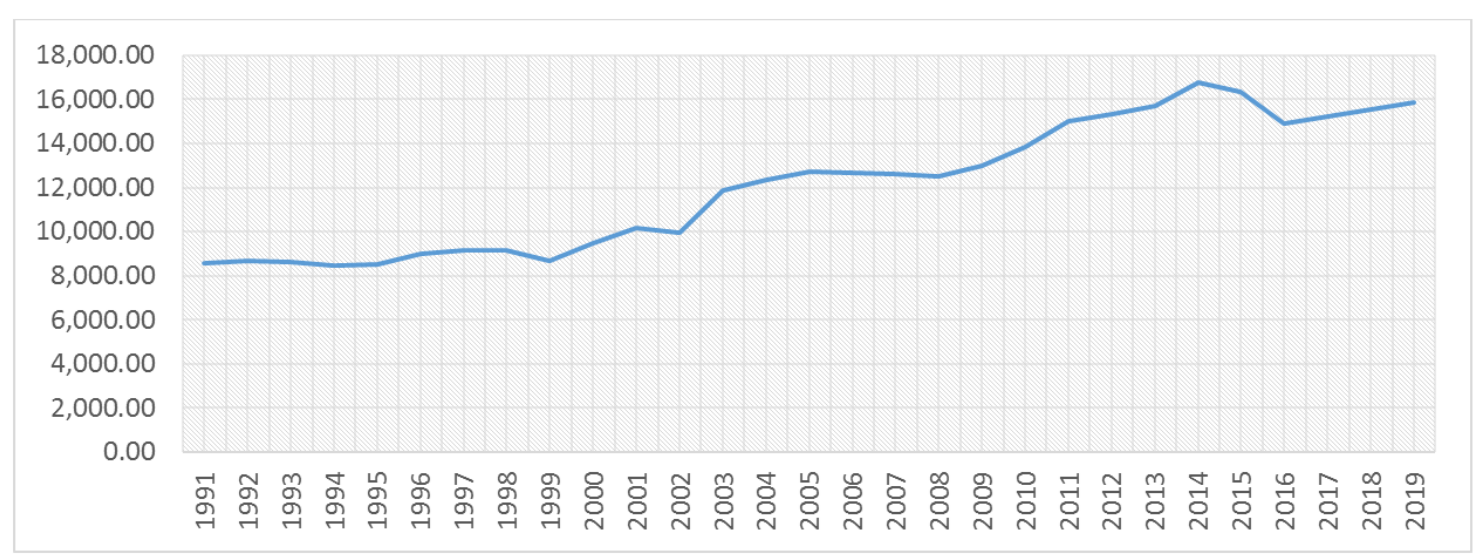

Figure 2. Industrial Output at Current Basic Prices.

One could expect that the increase in output should be matched with attendant decrease in youth unemployment since more labour will be required to produce such additional outputs. However, youth unemployment has been on the rising. Several empirical studies have been conducted to examine the link between industrialization and growth as well as that between unemployment and growth. However, there have been very few studies (some which are descriptive like [9]) on the linkages between industrialization and youth unemployment in Nigeria. This study therefore strives to fill such gap. It is in this light that this paper seeks to investigate the influence of industrialization on youth unemployment in Nigeria for the period 1991 to 2019.

The paper is structured in five sections. Section 1 is the introduction while Section 2 covers the literature review. The methodology of the research is adumbrated in Section 3 while empirical findings are presented in Section 4. Section 5 captures the conclusion and recommendations.

\section{Literature Review}

\subsection{Theoretical Literature}

This study is based on the Structural-Change model. The structural-change theory states that an economy's "underdevelopment is due to underutilization of resources arising from structural or institutional factors that have their origin in both domestic and international dualisms hence, development requires more than just accelerated capital formation" [10]. Lewis model of modern-sector growth in a two-sector surplus-labour economy is one of such models. According to the Lewis model, the underdeveloped economy is made up of two sectors: a traditional, overpopulated rural subsistence sector characterized by zero marginal productivity of labour-a situation that permits Lewis to classify this as surplus labour in the sense that it can be withdrawn from the traditional agricultural sector without any loss of output-and a high-productivity modern urban industrial sector into which labour from the subsistence sector is gradually transferred [10]. Such labour transfer as a result of the growth in the modern sector promotes industrialization and stimulate sustained development [10]. The Lewis theory was used in studying the recent growth experience in China and labour markets in other developing countries (see [11] and [12]). According to the StructuralChange Models, surplus labour is transferred to the modern sector, and it was believed that this would ensure cumulative growth of incomes, employment and rapid structural transformation of the developing economies [13].

\subsection{Empirical Literature}

The empirical literature on the role of industrialization on economic growth has been enormous but very few studies have been conducted on the effect of industrialization on youth unemployment. One of such studies is the study by [14] who examined how industrialization and economic growth affect employment generation in Nigeria using time series data for the period 1990 to 2016 . The study employed the ordinary least squares (OLS) technique and it was observed that economic growth has positive effect on employment while industrialization does not exert any significant effect on employment in Nigeria. The study recommended that policies that will encourage industrial strategy that promote employment generation should be encouraged.

Similarly, [15] argued that there exists a negative relationship between industrialization and income poverty in industrialized economies having lower poverty. This is because industrialization reduces poverty through increase in industrial output and employment and also a multiplier effects on other sectors of the economy. It is worth noting that employment multiplier in manufacturing are often higher than that of other sectors of the economy in that one job in manufacturing generally creates two-three jobs in the other sectors [16].

[17] in his study on finding solutions to unemployment and poverty through the promotion of sustainable economic growth and industrialization opined that true growth increases individual and national competencies. However, a mere increase in GDP, foreign reserves, and capital investment do not increase individual and national competences and thus constitutes trivial growth. He further argued that the rate of industrialization can be increased by 
increasing the learning rate in a society [9].

[9] investigated industrial development and youth unemployment in Ebonyi State of Nigeria using the Crushed Rock Quarrying Industry in Ishiagu, Ivo Local Government Area as a case study. The study employed descriptive approach of simple percentages and Spearman's rank correlation and the findings of the study revealed that employment of indigenous youths by the industry has reduced youth unemployment. They concluded the study by stating that it is only rapid industrialisation targeted at massive youth employment, development of local resources and technologies, human capacity building, rural development and effective government supervision/monitoring of industries that can contend the problems of industrialisation and youth unemployment in Nigeria.

\section{Methodology}

\subsection{Basic Research Design}

This paper employs an econometric approach in examining the influence of industrial sector on youth unemployment in Nigeria. Data were obtained from the Central Bank of Nigeria statistical bulletin, National Bureau of Statistics, and World Development Indicators - a publication of World Bank. The data were subjected to diagnostic test and were analysed using statistical software.

\subsection{Model Specification}

In examining the influence of the industrial sector on youth unemployment in Nigeria, the model for the study is specified as follows:

$$
\mathrm{YUNM}=\vartheta_{0}+\vartheta_{1} \mathrm{INDQ}+\vartheta_{2} \mathrm{BCIS}+\vartheta_{3} \mathrm{INTR}+\vartheta_{4} \mathrm{INFR}+\vartheta_{5} \mathrm{BMSS}+\vartheta_{6} \mathrm{GOVT}+\vartheta_{7} \mathrm{POPG}+\vartheta_{8} \mathrm{TOPN}+\mu
$$

Where:

YUNM=Youth unemployment rate

INDQ=Industrial output

BCIS $=$ Bank credit to the industrial sector

INTR $=$ Interest rate

INFR=Inflation rate

$\mathrm{BMSS}=$ Broad money supply
GOVT $=$ Government expenditure on economic services $\mathrm{POPG}=$ Population growth rate TOPN $=$ Trade openness

$\vartheta_{0}$ to $\vartheta_{8}$ parameters to be estimated $\mu=$ random error term

Transforming Equation (1) into an ARDL model, we have:

$$
\begin{gathered}
\mathrm{YUMN}_{\mathrm{t}}=\lambda+\sum_{i=1}^{p} \gamma_{\mathrm{i}} \mathrm{YUNM}_{\mathrm{t}-\mathrm{I}}+\sum_{i=0}^{q} \beta_{i} \mathrm{INDQ}_{\mathrm{t}-\mathrm{i}}+\sum_{i=0}^{q} \alpha_{i} \mathrm{BCIS}_{\mathrm{t}-\mathrm{i}}+\sum_{i=0}^{q} \theta_{i} \mathrm{INTR}_{\mathrm{t}-\mathrm{i}}+ \\
\sum_{i=0}^{q} \rho_{i} \mathrm{INFR}_{\mathrm{t}-\mathrm{i}}+\sum_{i=0}^{q} \varphi_{i} \mathrm{BMSS}_{\mathrm{t}-\mathrm{i}}+\sum_{i=0}^{q} \omega_{i} \mathrm{GOVT}_{\mathrm{t}-\mathrm{i}}+\sum_{i=0}^{q} \phi_{i} \mathrm{POPG}_{\mathrm{t}-\mathrm{i}}+\sum_{i=0}^{q} \pi_{i} \mathrm{TOPN}_{\mathrm{t}-\mathrm{i}}+\mu
\end{gathered}
$$

Where $\mathrm{p}$ and $\mathrm{q}$ represent the optimal lag length of the dependent and explanatory variables respectively; $\gamma, \beta, \alpha, \theta$, $\rho, \varphi, \omega, \phi$, and $\pi$ are the coefficients; $\lambda$ is the constant; $i=1, \ldots$, $\mathrm{k}$ for the dependent variable but $\mathrm{i}=0,1, \ldots, \mathrm{k}$ for the explanatory variables; and $\mu \mathrm{t}$ is the vector of the error termsunobservable zero mean white noise vector process (serially uncorrelated or independent).

\subsection{A priori Expectations}

From equation 1 , it is expected that $\vartheta_{1}, \vartheta_{2}, \vartheta_{4}, \vartheta_{5}$, and $\vartheta_{6}$ should be negative while $\vartheta_{3}, \vartheta_{7}$, and $\vartheta_{8}$ should all be positive.

\subsection{Data Source}

Data for the study were obtained from the Central Bank of Nigeria statistical bulletin, National Bureau of Statistics, and the World Development Indicator. In particular, data on YUNM and POPG were obtained from World Development Indicators while data on INDQ, BCIS, INTR, INFR, BMSS, GOVT, and TOPN were all obtained from the Central Bank of Nigeria Statistical Bulletin.

\subsection{Analytical Technique}

The analytical techniques here start from the unit root test

$$
\begin{gathered}
\Delta Y U N M_{t}=\beta 0+\sum_{i=1}^{P} \beta_{1 i} \Delta Y U N M_{t-i}+\sum_{i=1}^{q} \beta_{2 i} \Delta I N D Q_{t-i}+\sum_{i=1}^{q} \beta_{3 i} \Delta B C I S_{t-i}+\sum_{i=1}^{p} \beta_{4 i} \Delta I N T R_{t-i}+\sum_{i=1}^{q} \beta_{5 i} \Delta I N F R_{t-i}+ \\
\sum_{i=1}^{q} \beta_{6 i} \Delta B M S S_{t-i}+\sum_{i=1}^{q} \beta_{7 i} \Delta G O V T_{t-i}+\sum_{i=1}^{q} \beta_{8 i} \Delta P O P G_{t-i}+\sum_{i=1}^{q} \beta_{9 i} \Delta T O P N_{t-i}+\lambda E C M_{t-1}+\mu \mathrm{t}
\end{gathered}
$$

Where: correction mechanism.

The unit root test follows the Augmented Dickey-Fuller technique and a confirmation being done with the PhilipPeron approach. The rationale behind this test is that regressing a non-stationary time series with another nonstationary time series variable will lead to a spurious regression result. Thus, the need to determine the order of integration of the variables to decide on the appropriate approach to be adopted for the analysis.

The ARDL Bounds test for cointegration is utilized to determine whether there is any levels relationship when nonstationary time series variables are regressed. Thus, the essence is to determine the presence of a long-run relationship among the variables.

With the presence of a long-run relationship, the use of the error correction mechanism becomes pertinent. The error correction mechanism adjusts the short-run dynamics moving cointegration, the error correction model (ECM) representation is specified as: to the ARDL Bounds test for cointegration and then, the error the model towards equilibrium in the long-run. When there is 
negative sign

$\mathrm{ECM}=\left(Y U N M_{t-i}-\theta X_{t}\right)$, the error correction term

$\theta=\frac{\sum_{i=0}^{q} \beta_{i}}{\beta}$, is the long-run parameter

$\beta_{1 i}$ to $\beta_{9 i}=$ the short-run dynamic coefficients of the model's adjustment long-run equilibrium.

\section{Empirical Findings}

\subsection{Stylized Facts on Youth Unemployment in Nigeria}

Key facts are embedded on the nature of youth unemployment in Nigeria. These facts are presented in Table 1.

Table 1. Youth population and unemployment/underemployment in Nigeria.

\begin{tabular}{llll}
\hline Year & Population & Unemployment & Underemployment \\
\hline 2010 & $27,335,153$ & 6.8 & 21.9 \\
2011 & $28,209,878$ & 8.0 & 24.2 \\
2012 & $39,914,210$ & 12.5 & 19.2 \\
2013 & $33,927,916$ & 13.8 & 20.4 \\
2014Q1 & $34,183,367$ & 10.9 & 24.2 \\
2014Q2 & $34,372,543$ & 10.3 & 24.5 \\
2014Q3 & $34,615,024$ & 13.4 & 21.3 \\
2014Q4 & $34,799,095$ & 8.9 & 24.7 \\
2015Q1 & $35,039,814$ & 10.4 & 22.9 \\
2015Q2 & $35,313,934$ & 11.3 & 25.3 \\
2015Q3 & $36,380,320$ & 13.7 & 23.9 \\
2015Q4 & $36,720,239$ & 14.5 & 25.8 \\
2016Q1 & $38,249,628$ & 16.4 & 25.8 \\
2016Q2 & $39,569,148$ & 18.4 & 26.1 \\
2016Q3 & $40,155,660$ & 19.1 & 26.6 \\
2016Q4 & $40,739,520$ & 19.4 & 28.0 \\
2017Q1 & $40,992,737$ & 19.2 & 27.0 \\
2017Q2 & $41,779,450$ & 22.3 & 27.4 \\
2017Q3 & $43,015,540$ & 25.5 & 27.2 \\
2017Q4 & $42,630,875$ & 26.6 & 26.4 \\
2018Q1 & $43,412,870$ & 29.0 & 26.1 \\
2018Q2 & $44,163,821$ & 30.5 & 25.6 \\
2018Q3 & $44,229,419$ & 29.7 & 25.7 \\
\hline
\end{tabular}

Source: National Bureau of Statistics, 2018
Table 1 presents the stylized facts on the issue of youth unemployment and underemployment in Nigeria within the period 2010 and third quarter of 2018. As at 2010, the youth population stood at $27,335,153$ with a $6.8 \%$ being unemployed and $21.9 \%$ being underemployed. This therefore implies that about $1,858,790$ youths were totally unemployed while 5,986,398 were underemployed. Beyond this period, unemployment and underemployment in Nigeria maintained an upward trend reaching a record high of $13.4 \%$ and $21.3 \%$ respectively as at third quarter of 2014.

The values keep on rising over the years to a record high of $26.6 \%$ and $26.4 \%$ respectively as at fourth quarter of 2017 representing a total of $11,339,813$ unemployed youths and $11,254,551$ underemployed youths. Youth unemployment further reached a record high of $29.7 \%$ as at third quarter of 2018 with attendant underemployment rate of $25.7 \%$. As at 2019 , youth unemployment rate stood at $13.96 \%$ [18].

It is observed that in Nigeria, there is also high prevalence of youth underemployment. Thus, a lot of youths who are assumed to be working works below their full capacity. To be fully employed, it is expected that an individual works for not less than $40+$ hours per week. This means that a greater proportion of the youthful labour force have not been put to effective and efficient use. Also, population growth rate is a key issue of concern relating to youth unemployment and underemployment in Nigeria. As at 2010 when the youth population was $27,335,153$, youth unemployment was $6.8 \%$ but as the population rises to as high as $44,229,419$ in the third quarter of 2018, youth unemployment also rose to $29.7 \%$. whether this exert a significant effect on youth unemployment will be examined empirically is section 4 of this paper.

\subsubsection{Descriptive Statistics}

The descriptive statistics of the variables in the study is presented in Table 2 .

Table 2. Summary of the Descriptive Statistics of the Variables.

\begin{tabular}{|c|c|c|c|c|c|c|c|c|c|}
\hline & YUNM & BCIS & BMSS & GOVT & INDQ & INFR & INTR & TOPN & POPG \\
\hline Mean & 9.921 & 1798.94 & 8846.45 & 463.81 & 12095.13 & 18.599 & 18.50 & 35.221 & 2.578 \\
\hline Median & 9.500 & 524.570 & 2637.91 & 341.90 & 12527.1 & 12.218 & 17.95 & 36.400 & 2.586 \\
\hline Maximum & 13.96 & 6257.22 & 34251.7 & 1473.2 & 16742.2 & 72.835 & 29.80 & 58.918 & 2.681 \\
\hline Minimum & 7.810 & 11.453 & 75.401 & 4.448 & 8457.85 & 5.382 & 13.54 & 18.047 & 2.489 \\
\hline Std. Dev. & 1.538 & 2186.98 & 10614.4 & 380.07 & 2903.55 & 17.078 & 3.117 & 9.459 & 0.071 \\
\hline Skewness & 1.865 & 1.055 & 1.020 & 0.755 & 0.097 & 2.030 & 1.813 & 0.269 & 0.089 \\
\hline Jarque-Bera & 23.50 & 5.489 & 5.125 & 2.762 & 2.758 & 30.362 & 39.94 & 0.351 & 3.007 \\
\hline (Probability) & $(0.000)$ & $(0.064)$ & $(0.077)$ & $(0.251)$ & $(0.252)$ & $(0.000)$ & $(0.000)$ & $(0.839)$ & $(0.22)$ \\
\hline Sum & 287.710 & 52169. & 256547.1 & 13450.44 & 350758.8 & 539.375 & 536.382 & 1021.397 & 74.753 \\
\hline Sum Sq. Dev. & 66.273 & $1.34 \mathrm{E}+08$ & $3.15 \mathrm{E}+09$ & 4044794 . & $2.36 \mathrm{E}+08$ & 8167.136 & 272.096 & 2505.471 & 0.143 \\
\hline Observations & 29 & 29 & 29 & 29 & 29 & 29 & 29 & 29 & 29 \\
\hline
\end{tabular}

Source: Authors Computation from Eviews 10.

The sample size is 29 which covers the period 1991 to 2019. Youth unemployment (YUNM) between the two period averaged $9.921 \%$ with a minimum and maximum rate being $7.180 \%$ and $13.96 \%$ respectively. Similarly, the value of industrial output averaged $\$ 12,095.13$ billion with a minimum and maximum value of $\$ 8,457.85$ billion and $\$ 16,742.2$ billion respectively. The same analogy is applicable to other variables. All the variables are observed to 
be positively skewed.

\subsubsection{Correlation Matrix}

The correlation coefficient is presented in Table 3 .

Table 3. Correlation Coefficients.

\begin{tabular}{|c|c|c|c|c|c|c|c|c|c|}
\hline & YUNM & BCIS & BMSS & GOVT & INDQ & INFR & INTR & TOPN & POPG \\
\hline YUNM & 1 & 0.6700 & 0.686 & 0.546 & 0.350 & -0.063 & -0.197 & -0.387 & 0.085 \\
\hline BCIS & & 1 & 0.989 & 0.809 & 0.848 & -0.317 & -0.444 & -0.643 & 0.637 \\
\hline BMSS & & & 1 & 0.849 & 0.869 & -0.331 & -0.462 & -0.613 & 0.659 \\
\hline GOVT & & & & 1 & 0.802 & -0.474 & -0.505 & -0.404 & 0.730 \\
\hline INDQ & & & & & 1 & -0.500 & -0.532 & -0.498 & 0.880 \\
\hline INFR & & & & & & 1 & 0.428 & 0.194 & -0.477 \\
\hline INTR & & & & & & & 1 & 0.046 & -0.461 \\
\hline TOPN & & & & & & & & 1 & -0.370 \\
\hline POPG & & & & & & & & & 1 \\
\hline
\end{tabular}

Source: Authors Computation from Eviews 10.

From Table 3, each variable is perfectly correlated with itself implying the perfect correlation coefficient of 1 . Youth unemployment rate is positively correlated with BCIS, BMSS, GOVT, INDQ, and POPG implying that as these variables increases, youth unemployment also increases. Also, INFR, INTR, and TOPN are inversely related to youth unemployment implying that as the variables increases, youth unemployment decreases. However, correlation among the variables does not in any way imply causation.

\subsubsection{Diagnostic Test}

The diagnostic test here is the unit root test and is conducted using both the Augmented Dickey Fuller and the Philip-Peron approaches. The two approaches are conducted using the constant linear trend assumption. The result is presented in Table 4.

Table 4. Unit Root Test Result.

\begin{tabular}{|c|c|c|c|c|c|}
\hline \multicolumn{6}{|c|}{ Augmented Dickey Fuller (ADF) Test } \\
\hline Variable & Level & Probability & First Difference & Probability & Order of Integration \\
\hline YUNM & -1.327 & 0.860 & 1.475 & 0.999 & $\mathrm{~N} / \mathrm{S}$ \\
\hline BCIS & -1.182 & 0.895 & $-4.914 * * *$ & 0.003 & I (1) \\
\hline BMSS & 0.683 & 0.999 & $-4.840 * * *$ & 0.003 & I (1) \\
\hline GOVT & -1.731 & 0.710 & $-4.400 * * *$ & 0.008 & I (1) \\
\hline INDQ & -3.089 & 0.130 & $-4.444 * * *$ & 0008 & I (1) \\
\hline INTR & -4.370 & $0.011 * * *$ & $-6.226 * * *$ & 0.000 & $\mathrm{I}(0)$ \\
\hline TOPN & -3.898 & $0.026 * * *$ & $-7.067 * * *$ & 0.000 & $\mathrm{I}(0)$ \\
\hline POPG & -3.155 & 0.115 & -1.688 & 0.728 & $\mathrm{~N} / \mathrm{S}$ \\
\hline \multicolumn{6}{|c|}{ Philip-Peron (PP) Unit Root Test } \\
\hline Variable & Level & Probability & First Difference & Probability & Order of Integration \\
\hline YUNM & -1.333 & 0.858 & $-5.315 * * *$ & 0.001 & $\mathrm{I}(1)$ \\
\hline BCIS & -1.076 & 0.916 & $-4.917 * * *$ & 0.003 & I (1) \\
\hline GOVT & -2.106 & 0.521 & $-4.398 * * *$ & 0.009 & I (1) \\
\hline INDQ & -2.340 & 0.401 & $-4.416 * * *$ & 0.008 & I (1) \\
\hline INFR & -2.963 & 0.160 & $-5.564 * * *$ & 0.001 & I (1) \\
\hline INTR & $-5.425^{* * *}$ & 0.001 & $-20.775^{* * *}$ & 0.000 & $\mathrm{I}(0)$ \\
\hline TOPN & $-3.742 * *$ & 0.036 & $-11.778 * * *$ & 0.000 & $\mathrm{I}(0)$ \\
\hline POPG & -1.846 & 0.665 & $-4.906 * *$ & 0.024 & I (1) \\
\hline
\end{tabular}

Source: Authors Computation from Eviews 10.

Note: $* *$ and $* * *$ denote significance at $5 \%$ and $1 \%$ respectively.

The result of the unit root test in Table 4 indicates mixture of order of integration by both the ADF and PP techniques. The only point of divergence between the two test is in regards to YUNM and POPG. YUNM and POPG are reported to be nonstationary $(\mathrm{N} / \mathrm{S})$ by the ADF technique but stationary at first difference under the PP technique. The result from the PP technique is accepted since the technique is considered more powerful. Interest rate and inflation rate are stationary at level, I (0), while all other variables are stationary at first difference, I (1). This mixed order of integration necessitates the use of the ARDL Bounds test to detect whether there is an existence of a long-run relationship 
among the variables.

\subsubsection{The ARDL Regression}

The ARDL regression result follows ARDL $(1,2,1,1,1,2,2$, $1,2)$. The result is obtained after 6,561 models were estimated. The optimal lag was automatically selected using the Akaike Information Criterion. The result is presented in Table 5.

Table 5. ARDL Short-Run Regression Result

\begin{tabular}{lllll}
\hline Variables & Coefficients & $\begin{array}{l}\text { Standard } \\
\text { Error }\end{array}$ & t-statistic & Probability \\
\hline YUNM (-1) & 0.3785 & 0.2419 & 1.5646 & 0.1784 \\
BCIS & $0.0021^{* *}$ & 0.0006 & 3.4464 & 0.0183 \\
BCIS (-1) & 0.0004 & 0.0005 & 0.7065 & 0.5114 \\
BCIS (-2) & $0.0016^{* *}$ & 0.0005 & 3.0681 & 0.0278 \\
BMSS & -0.0001 & 0.0002 & -0.6264 & 0.5585 \\
BMSS (-1) & -0.0002 & 0.0003 & -0.6818 & 0.5257 \\
INDQ & -0.0005 & 0.0004 & -1.2858 & 0.2548 \\
INDQ (-1) & -0.0007 & 0.0004 & -1.8942 & 0.1167 \\
GOVT & -0.0024 & 0.0012 & -1.9540 & 0.1081 \\
GOVT (-1) & -0.0027 & 0.0016 & -1.7243 & 0.1453 \\
INFR & -0.0084 & 0.0163 & -0.5133 & 0.6296 \\
INFR (-1) & 0.0029 & 0.0273 & 0.1072 & 0.9188 \\
INFR (-2) & -0.0252 & 0.0218 & -1.1567 & 0.2997 \\
INTR & $0.2118^{*}$ & 0.1011 & 2.0943 & 0.0904 \\
INTR (-1) & 0.0567 & 0.0583 & 0.9728 & 0.3753 \\
INTR (-2) & $0.1551^{*}$ & 0.0736 & 2.1062 & 0.0890 \\
POPG & $58.0706^{*}$ & 24.5489 & 2.3655 & 0.0643 \\
POPG (-1) & $-31.2069^{*}$ & 15.2673 & -2.0440 & 0.0964 \\
TOPN & $0.0730^{*}$ & 0.0314 & 2.3252 & 0.0676 \\
TOPN (-1) & 0.0306 & 0.0208 & 1.4695 & 0.2017 \\
TOPN (-2) & $0.0703^{*}$ & 0.0291 & 2.4157 & 0.0604 \\
C & $-64.5314^{*}$ & 31.8867 & -2.0238 & 0.0989 \\
\hline
\end{tabular}

$\mathrm{R}^{2=} 0.9889$ F-statistic $=21.154(0.000)$

Adjusted $\mathrm{R}^{2}=0.9421$ Durbin Watson $=2.14$

Source: Authors Computation using Eviews 10.

Note: $*$ and $* *$ denote significance at $10 \%$ and $5 \%$ respectively.

Table 5 depicts dynamic regression with an optimal lag of two. For example, YUMN has a one-period lag while TOPN has a two-period lags. From the estimates, it is observed that youth unemployment (YUNM) increases itself by $0.3785 \%$ in the first period lag. Also, BCIS, INTR, POPG, and TOPN exert a positive effect on YUNM though some with insignificant effect. The result shows that a $\$ 1$ billion increase in BCIS will lead to a $0.0021 \%$ increase in YUNM. This effect is statistically significant at the 5\% level. Also, the first and second period lag of BCIS exert a positive effect on YUNM. Broad money supply (BMSS) and its lags are observed to exert a negative, though insignificant, effect on YUNM. This implies that a $\$ 1$ billion increase in BMSS will lead to a $0.0001 \%$ decrease in YUNM. Industrial output (INDQ) and its lag are also seen to exert a negative but insignificant effect on youth unemployment as well as government expenditure on economic services in the short-run.

Inflation rate (INFR) also exert a negative but insignificant effect on youth unemployment while interest rate (INTR) and its lags exert a negative effect. Thus, a unit percentage increase in inflation rate and interest rate will lead to a $0.0084 / 0.2118$ decrease/increase in youth unemployment in the short-run. Population growth rate (POPG) is observed to have a positive and significant effect on youth unemployment. Thus, a unit percentage increase in population growth will lead to $58.07 \%$ increase in youth unemployment. Trade openness (TOPN) and its lags indicates a positive and significant effect on youth unemployment. Thus, a unit percentage increase in trade openness will lead to a $0.073 \%$ increase in youth unemployment in the short-run.

The coefficient of multiple determination $\left(\mathrm{R}^{2}\right)$ which is 0.9889 is very high and indicates a high goodness of fit. It implies that the explanatory variables explain $98.89 \%$ of the total variations in youth unemployment in the short-run. Also, the explanatory power of the model $(0.9421=94.21 \%)$ still remains quite high after being adjusted for the degree of freedom. The F-statistic (21.154) is statistically significant at the $5 \%$ level as indicated by the probability of 0.0002 . this means that the overall model is statistically significant in explaining the variations in the dependent variable. The Durbin-Watson statistic of 2.14 is approximately 2 and is an indication that there is absence of serial correlation.

These short-run dynamics in the model therefore call for an investigation into the existence of a long-run relationship in the model. We therefore proceed to examining such existence through the ARDL Bounds test for cointegration.

\subsubsection{ARDL Bounds Test for Cointegration}

The long-run relationship among the variables is presented in Table 6.

Table 6. Long-Run Test for Integration.

\begin{tabular}{lllll}
\hline F-Bounds Test & & \multicolumn{4}{l}{ Null Hypothesis: No levels relationship } \\
\hline Test Statistic & Value & Significance & I (0) & I (1) \\
\hline F-statistic & 7.521 & $10 \%$ & 1.85 & 2.85 \\
k & 8 & $5 \%$ & 2.11 & 3.15 \\
& & $2.5 \%$ & 2.33 & 3.42 \\
& & $1 \%$ & 2.62 & 3.77 \\
\hline
\end{tabular}

Source: Authors Computation from Eviews 10.

From Table 6, the F-statistic (7.521) is greater than the 5\% lower bound (I (0)) and upper bound, I (1) of 2.11 and 3.15 respectively. The F-statistics is therefore statistically significant at the 5\% level. Thus, the null hypothesis of no levels relationship is rejected. Thus, there exist a long-run relationship between youth unemployment and industrial output in Nigeria. Hence, we proceed to the error correction model.

\subsubsection{Error Correction Mechanism}

The result of the error correction mechanism is presented in Table 7.

Table 7. Result of the Error Correction Mechanism.

\begin{tabular}{lllll}
\hline Variable & Coefficient & Std. Error & t-Statistic & Prob. \\
\hline D (BCIS) & $0.0021 * * *$ & 0.0002 & 11.335 & 0.0001 \\
D (BCIS (-1)) & $-0.0016 * * *$ & 0.0002 & -8.0514 & 0.0005 \\
D (BMSS) & $-0.0001 *$ & $5.32 \mathrm{E}-05$ & -2.140 & 0.0853 \\
D (GOVT) & $-0.0024 * * *$ & 0.0004 & -5.993 & 0.0019 \\
D (INDQ) & $-0.0005 * * *$ & $9.61 \mathrm{E}-05$ & -4.722 & 0.0052 \\
D (INFR) & -0.0084 & 0.0057 & -1.476 & 0.1999 \\
D (INFR (-1)) & $0.0252 * * *$ & 0.0049 & 5.119 & 0.0037 \\
\hline
\end{tabular}




\begin{tabular}{lllll}
\hline Variable & Coefficient & Std. Error & t-Statistic & Prob. \\
\hline D (INTR) & $0.2118^{* * *}$ & 0.0232 & 9.129 & 0.0003 \\
D (INTR (-1)) & $-0.1551^{* * *}$ & 0.0195 & -7.936 & 0.0005 \\
D (POPG) & $58.071^{* * *}$ & 5.5677 & 10.430 & 0.0001 \\
D (TOPN) & $0.073^{* * *}$ & 0.0068 & 10.748 & 0.0001 \\
D (TOPN (-1)) & $-0.0703^{* * *}$ & 0.0087 & -8.079 & 0.0005 \\
CointEq (-1)* & $-0.6215^{* * *}$ & 0.0428 & -14.511 & 0.0000 \\
\hline
\end{tabular}

$\mathrm{R}^{2}=0.9721$ Durbin Watson $=2.42$.

Adjusted $\mathrm{R}^{2}=0.9482$ Akaike Info Criterion $=0.187$.

Source: Author Computation using Eviews 10.

Note: * and $* * *$ denote significance at $10 \%$ and $1 \%$ respectively.

From the error correction model in Table 7, all the variables are observed to exert a significant effect on youth unemployment except inflation rate. In the long-run, a unit increase bank credit to the industrial sector (BCIS) will lead to a $0.0021 \%$ increase in youth unemployment while a unit percentage increase in broad money supply (BMSS) will lead to a $0.0001 \%$ decrease in unemployment. Also, government expenditure on economic services (GOVT) and industrial output (INDQ) exert negative effect on youth unemployment. This implies that a unit percentage increase in GOVT and INDQ will lead to a $0.0024 \%$ and $0.0005 \%$ decrease in youth unemployment respectively. Though INFR do not exert a significant effect, its first-lag exerts a positive and significant effect on youth unemployment. This implies that the firstperiod lag of interest rate reduces youth unemployment by $0.1551 \%$. population growth rate (POPG) and trade openness (TOPN) both exert a positive and significant effect on youth unemployment. Thus, a unit percentage increase in POPG and TOPN will lead to a $58.071 \%$ and $0.073 \%$ increase in youth unemployment.

The coefficient of the error correction term (CointEq $(-1)^{*}$ is rightly signed (negative) and statistically significant at the $1 \%$ level, and shows the speed of adjustment of the short-run disequilibrium to an equilibrium position in the long-run. The coefficient $(-0.6215)$ is an indication that $62.15 \%$ of the disequilibrium in the short-run is corrected annually. The goodness of fit of the regression remains high as captured by the $\mathrm{R}^{2}$ of $0.9721(97.21 \%)$ and the Durbin-Watson of 2.14 is an indication of no serial correlation in the long-run model.

\subsubsection{Post Diagnostic Test}

The various diagnostic tests here include heteroscedasticity test, serial correlation test, Ramsey reset test, and stability test. These various test are presented in Table 8 to Table 10 and in Figure 3 to Figure 5.

\subsubsection{Residual Diagnostic Test}

From Table 8, the F-statistic is not significant at the 5\% level as shown by the probability of 0.7712 . Thus, there is absence of Heteroscedasticity hence, there is homoscedasticity-the presence of constant variance.

Table 8. Heteroskedasticity Test: Breusch-Pagan-Godfrey.

\begin{tabular}{llll}
\hline F-statistic & 0.6617 & Prob. F (21,5) & 0.7712 \\
Obs*R-squared & 19.8553 & Prob. Chi-Square (21) & 0.5304 \\
Scaled explained SS & 0.7352 & Prob. Chi-Square (21) & 1.0000 \\
\hline
\end{tabular}

Source: Authors Computation using Eviews 10.

Table 9. Breusch-Godfrey Serial Correlation LM Test.

\begin{tabular}{llll}
\hline F-statistic & 9.592 & Prob. F $(2,3)$ & 0.0497 \\
Obs*R-squared & 23.349 & Prob. Chi-Square (2) & 0.0000 \\
\hline
\end{tabular}

Source: Authors Computation using Eviews 10.

The Breuch-Godfrey Serial Correlation LM test F-statistic is significant at $5 \%$. This implies that the null hypothesis of serial correlation is rejected at the $5 \%$ level.

Table 10. Ramsey Reset Test Omitted Variables: Squares of fitted values.

\begin{tabular}{llll}
\hline & Value & df & Probability \\
\hline t-statistic & 1.5710 & 4 & 0.1913 \\
F-statistic & 2.4681 & $(1,4)$ & 0.1913 \\
F-test summary: & & & \\
& Sum of Sq. & df & Mean Squares \\
Test SSR & 0.2777 & 1 & 0.2777 \\
Restricted SSR & 0.7278 & 5 & 0.1456 \\
Unrestricted SSR & 0.4501 & 4 & 0.1125 \\
\hline
\end{tabular}

Source: Authors Computation using Eviews 10.

The Ramsey Reset test captures the specification of the model. Since both the t-statistic and F-statistic (1.571 and 2.468 , respectively) are not significant at the $5 \%$ level of significance, the null hypothesis of specification error is rejected. Hence, the model is specified correctly.

\subsubsection{Stability Diagnostic Test}

The Cumulative Sum (CUSUM), CUSUM of squares, and Recursive Residuals serve as the stability test. This is represented in the figures below.

As depicted in Figure 3 to Figure 5, the CUSUM, CUSUM of Squares, and Recursive Residuals lines all lie within the $5 \% \pm 2$ Standard Error critical bounds. Therefore, the estimates of the long-run relationship is stable.

\subsection{Granger Causality Test}

This test is conducted to depict the nature of the relationship between youth unemployment and the explanatory variables in the model. The result is presented in Table 11.

Table 11. Granger Causality Test Result.

\begin{tabular}{|c|c|c|c|}
\hline Null Hypothesis: & Observation & F-Statistic & Prob. \\
\hline BCIS does not Granger Cause YUNM & 27 & 7.90246 & 0.0026 \\
\hline YUNM does not Granger Cause BCIS & & 22.5432 & 5. E-06 \\
\hline BMSS does not Granger Cause YUNM & 27 & 10.2893 & 0.0007 \\
\hline YUNM does not Granger Cause BMSS & & 1.48645 & 0.2480 \\
\hline
\end{tabular}




\begin{tabular}{|c|c|c|c|}
\hline Null Hypothesis: & Observation & F-Statistic & Prob. \\
\hline GOVT does not Granger Cause YUNM & 27 & 0.69490 & 0.5098 \\
\hline YUNM does not Granger Cause GOVT & & 4.85834 & 0.0179 \\
\hline INDQ does not Granger Cause YUNM & 27 & 3.49817 & 0.0480 \\
\hline YUNM does not Granger Cause INDQ & & 1.27854 & 0.2983 \\
\hline INFR does not Granger Cause YUNM & 27 & 0.15863 & 0.8543 \\
\hline YUNM does not Granger Cause INFR & & 0.10800 & 0.8981 \\
\hline YUNM does not Granger Cause INTR & & 0.47452 & 0.6284 \\
\hline POPG does not Granger Cause YUNM & 27 & 2.44899 & 0.1096 \\
\hline YUNM does not Granger Cause POPG & & 10.4825 & 0.0006 \\
\hline TOPN does not Granger Cause YUNM & 27 & 2.77154 & 0.0844 \\
\hline YUNM does not Granger Cause TOPN & & 0.00706 & 0.9930 \\
\hline
\end{tabular}

Source: Authors Computation using Eviews 10.

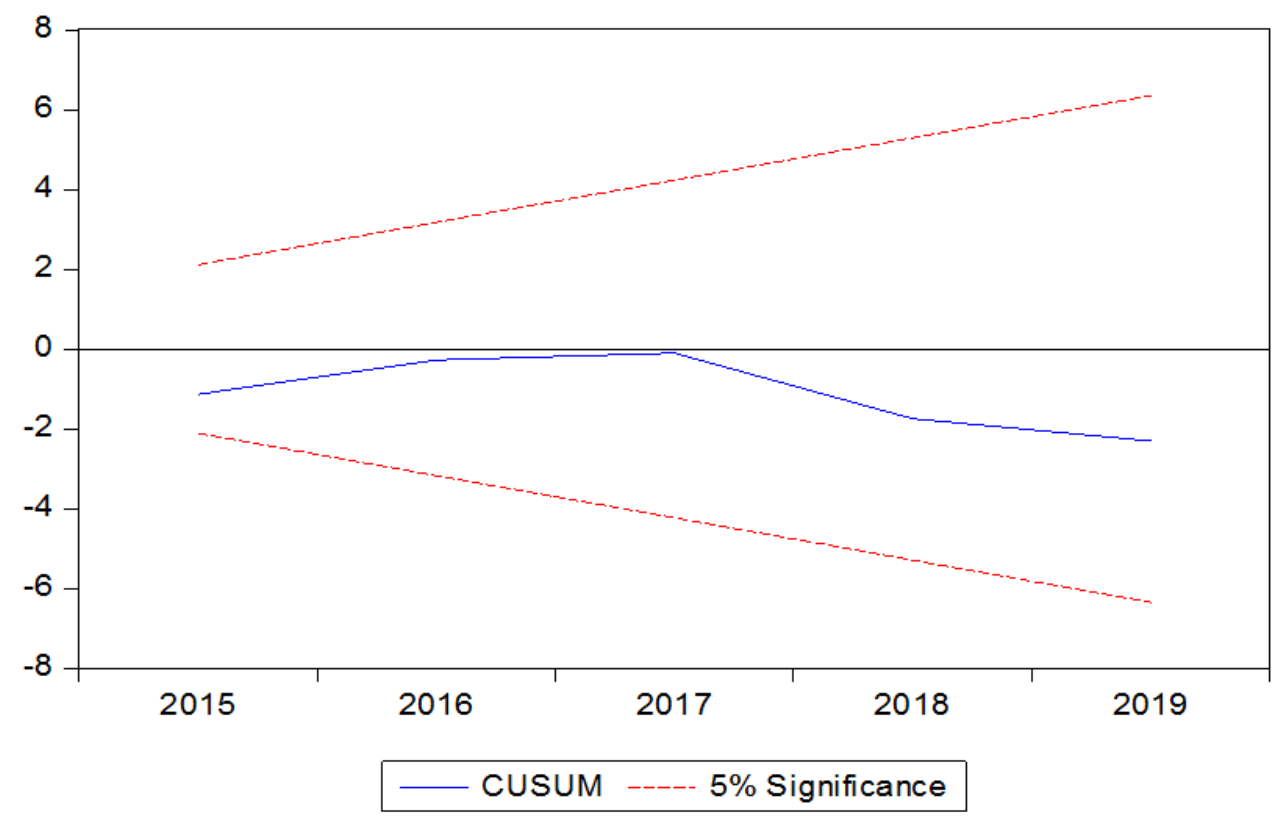

Figure 3. Cumulative Sum of Residuals.

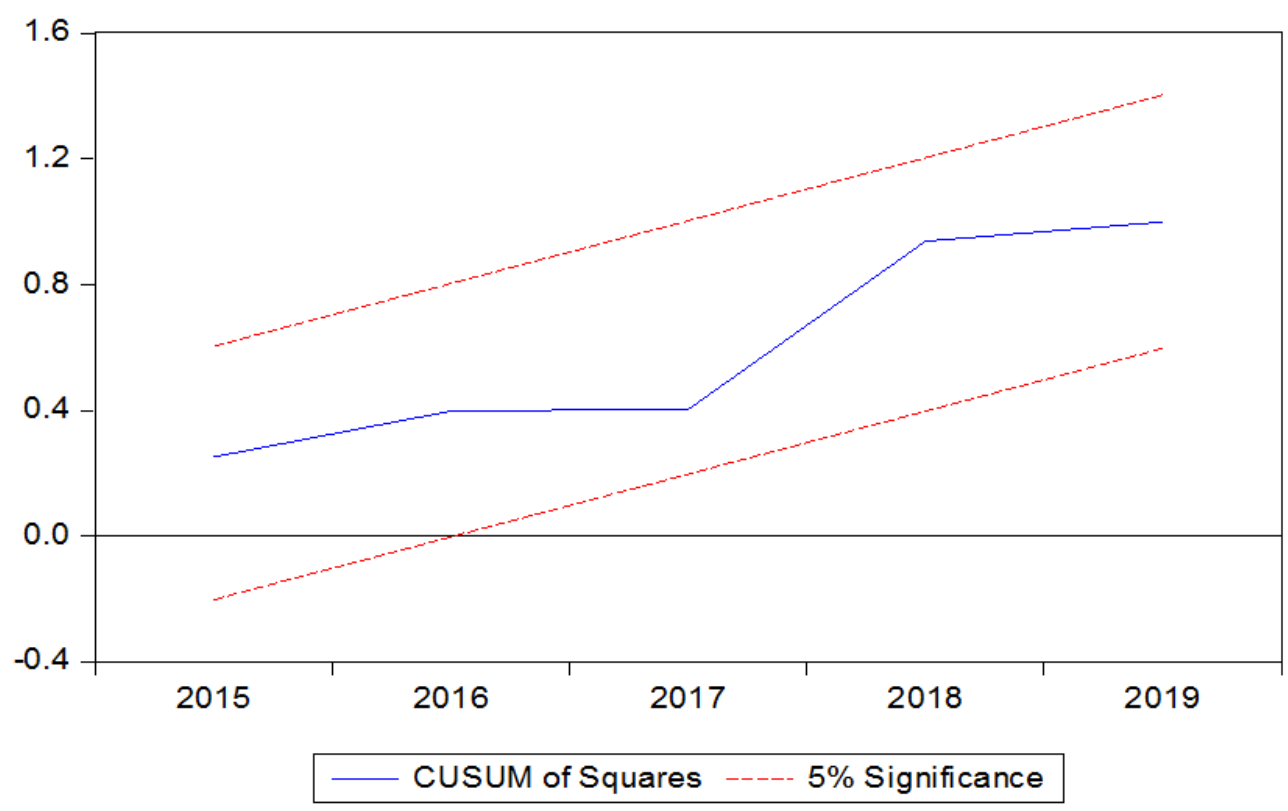

Figure 4. CUSUM of Squares of Residuals. 


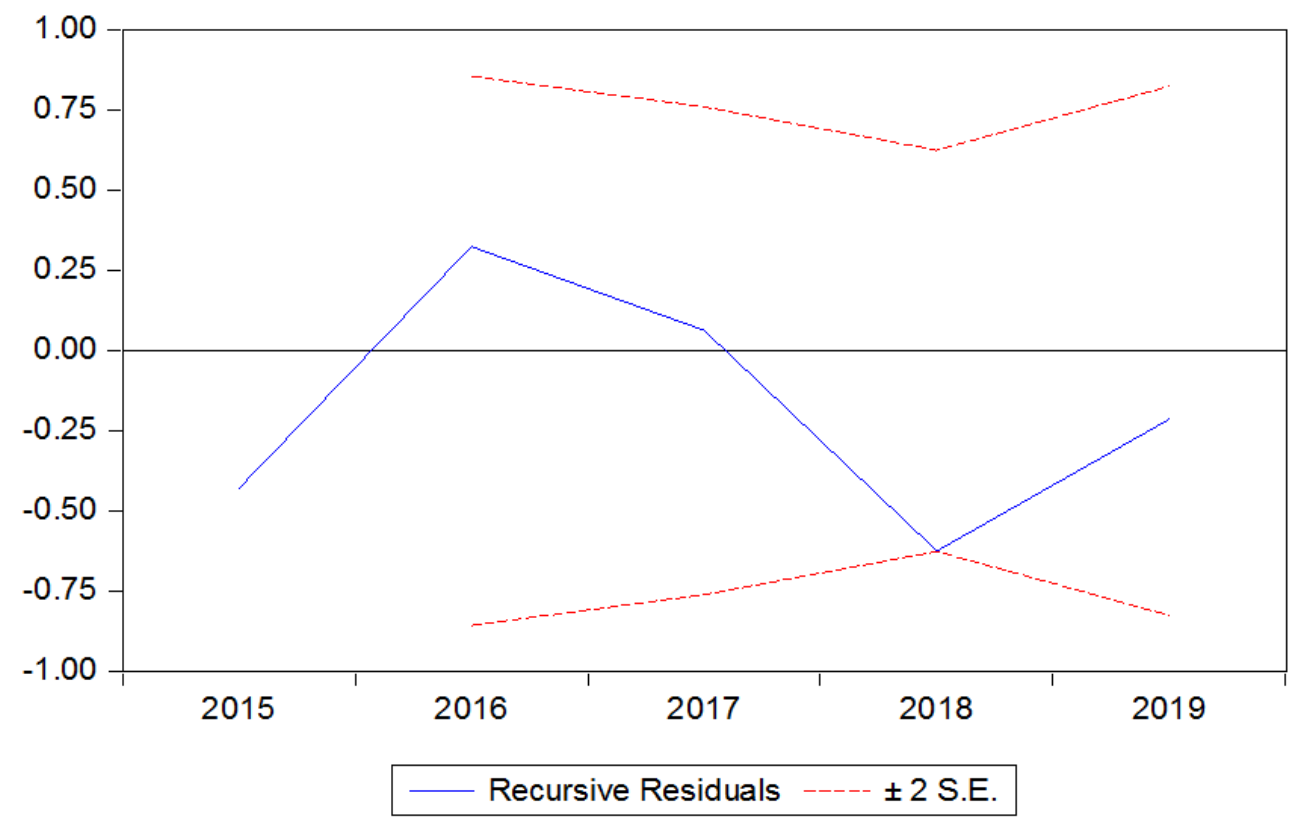

Figure 5. Recursive Residuals.

From the Granger causality test result, there is a bidirectional causality flowing between BCIS and YUNM. These effects are statistically significant at the $1 \%$ level of significance. Hence, bank credit to the industrial sector Granger cause youth unemployment and youth unemployment also Granger cause bank credit to the industrial sector. Also, a unidirectional causality flows between BMSS and YUNM. Thus, broad money supply Granger cause youth unemployment and not the other way round. Evidence of unidirectional causality between government expenditure on economic service and youth unemployment is also noted. Form Table 10, youth unemployment Granger cause government expenditure on economic services. Industrial output also Granger cause youth unemployment indicating a unidirectional causality while a unidirectional causality also flows form youth unemployment to population growth rate.

\subsection{Major Findings and Discussion of Findings}

The major findings of the study are as follows:

i. There is a negative and significant effect of industrialization on youth unemployment in the long run: As noted earlier, industrialization is believed to be an engine of structural transformation and a catalyst for job creation. The negative effect implies that high industrialization reduces youth unemployment since more job opportunities will be created. The a priori sign meets the expectation.

ii. Bank credit to the industrial sector exerts a positive and significant effect on youth unemployment in the longrun and in the short-run: Bank credit to the industrial sector is expected to boost industrial output which in turn increases youth employment. But here, it is observed that such effect is positive implying that high volume of bank credit to the industrial sector increases youth unemployment in Nigeria. This positive relationship can be traced to the fact that as industrialists obtain these loans, they can embark on massive automation which cut down on the number of labour required. Hence, bank credit to the industrial sector can promote capital-intensive mode of production rather than labour-intensive mode of production.

iii. Population growth rate exert a positive and significant effect on youth unemployment in Nigeria: It is expected that as the population grows beyond the available employment opportunities, there will be surplus of labour supply over demand. This therefore culminates to greater unemployment problem in the country.

iv. Interest rate exert positive and significant effect on youth unemployment in Nigeria: High interest rate will discourage borrowing by industrialists which will hinder their smooth operation. Thus, high interest rate impedes industrialization which in turn impede labour employment.

v. Government expenditure on economic services wields a negative and significant effect on youth unemployment in Nigeria: As government spends on economic services, especially on capital expenditures, jobs are created and youth unemployment is reduced.

\section{Conclusion and Recommendations}

This study was an empirical investigation into the effect of industrialization on youth unemployment in Nigeria for the period 1991 to 2019. The study employed the ARDL approach, the error correction mechanism and the Granger causality test. The result of the empirical analysis indicates that industrialization exerts a negative and significant effect on youth unemployment in Nigeria. This implies that increased industrialization will drastically reduce youth 
unemployment in the country. Thus, industrialization is truly a catalyst for structural transformation and job creation. Further, key variables like bank credit to the industrial sector, population growth rate, interest rate, and government expenditure were all seen to exert significant influence on youth unemployment. Based on these findings, the following recommendations are submitted:

i. There is need for a paradigm shift from the common idea that entrepreneurship eradicates youth unemployment. There is need for the promotion of a strong industrial base in the country as this will be a panacea for strengthening other key sectors of the economy that can also create more employment.

ii. Bank credit to the industrial sector should be channelled towards labour-friendly policies rather than on excessive automation. This will reduce job loss and create more employment opportunities.

iii. The population of the country needs to be checked to avoid population explosion. This can be achieved through proper education and family planning. Stringent legislations should be put in place to check on the number of children that a family can have. Lessons should be taken from China for instance. A greater population with massive unemployment mean no good for the well-being of the country.

iv. There is need to regulate interest rate to be industrialist-friendly. Industrial loans should be made available at interest rate that is least minimum possible to encourage borrowing.

v. There is need for government to invest on massive infrastructure so as to facilitate industrialization which in turn will create more jobs to the citizenry.

\section{References}

[1] Onah, F. O. (2001). Urban unemployment situation in Nigeria. In: Ezeani, E. O. and Elekwa, N. N. (eds.) Issues in Urbanization and Urban Administration in Nigeria, pp. 154167, Enugu: Jamo Enterprises.

[2] National Bureau of Statistics (2018). Labour force statistics, Volume 1: Unemployment and underemployment report.

[3] Folabi, F. (2013). "Obasanjo Sustains Anxiety in PDP”. Retrieved on 29/5/2013. https://dailyindependentnig.com/2013/03/as-obasanjosustains-anxiety-in-pdp.

[4] Onwukwe, N. U. (2003). Fundamentals of microeconomics. Abakaliki: Printwell Press Ltd.

[5] African Economic Outlook (2017). Entrepreneurship and industrialization. Available

at: www.africaneconomicoutlook.org.

[6] Lin, J. Y. and Monga, C. (2013). Comparative advantage: The silver bullet of industrial policy. In: J. E. Stiglitz and J. Y. Lin (eds.), The Industrial Policy Revolution 1: The Role of Government Beyond Ideology, pp. 19-38, UK: Palgrave Macmillan.

[7] Okurebia, S. O. (2014). Industrialization, youth employment and capacity utilization in Africa: Some fundamental problems. European Journal of Business and Management, Vol. 6, No. 27.

[8] Central Bank of Nigeria (2019). Statistical bulletin.

[9] Ukommi, A. S., Agha, E. O. and Ekpenyong, O. A. (2013). Industrial development and youth unemployment: The case of Crushed Rock Quarry Industry, Ishiagu in Ebonyi State. Knowledge Review, Volume 28, No. 1.

[10] Torado, M. P. and Smith, S. C. (2011). Economic development. Eleventh edition. Harlow: Pearson Education Limited.

[11] Islam, N. and Yokota, K. (2008). Lewis growth model and China's industrialization. Asian Economic Journal, 22, pp. 359-396.

[12] Zang, X., Yang, J. and Wang, S. (2010). China has reached the Lewis turning point. International Food Policy Research Institute (IFPRI) discussion paper, 977, Washington, D. C.

[13] Dauda, R. O. S. (2004). An economic assessment of the industrial sector in Nigeria's fledging fourth Republic. International Journal of Social Sciences, 3 (1): 136-149.

[14] Olusoji, M. O. and Oderinde, O. L. (2017). Industrialization, growth and employment in Nigeria. Selected Papers for the 2017 Conference Proceedings of the Nigerian Economic Society.

[15] Athukorala, P. and Sen, K. (2015). Industrialization, Employment and Poverty. Working Papers in Trade and Development, Arndt-Corden Department of Economics Crawford School of Public Policy, ANU College of Asia and the Pacific. Working Paper No. 2015.

[16] Lapova, A. and Szirmai, A. (2012). Industrialization, employment and poverty. UNU-MERIT Working Paper No. 81.

[17] Ogbimi, F. E. (2007). Promoting sustainable economic growth and industrialization: Solution to mass unemployment and poverty. African Journal of Traditional, Complementary and Alternative Medicines.

[18] World Bank (2019). World development indicators. Yipping, H. and Tingsong, J. (2010). What does the Lewis turning point mean for China? A computable general equilibrium analysis. China Centre for Economic Research Working Paper. 